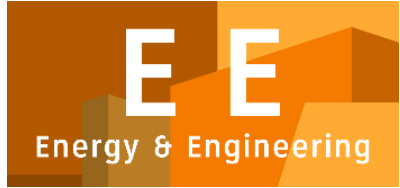

PAPER - OPEN ACCESS

\title{
Kajian Performansi Kompor Surya dengan Erythrytol Sebagai Pcm untuk Memasak Langsung dan Tidak Langsung
}

\author{
Author \\ : Safri Gunawan \\ DOI \\ ISSN \\ : $10.32734 /$ ee.v1i1.113 \\ E-ISSN \\ : 2654-7031 \\ : 2654-704X \\ Volume 1 Issue 1 - 2018 TALENTA Conference Series: Energy and Engineering
}

\section{(a) $(\mathbb{\theta})$}

This work is licensed under a Creative Commons Attribution-NoDerivatives 4.0 International License.

Published under licence by TALENTA Publisher, Universitas Sumatera Utara
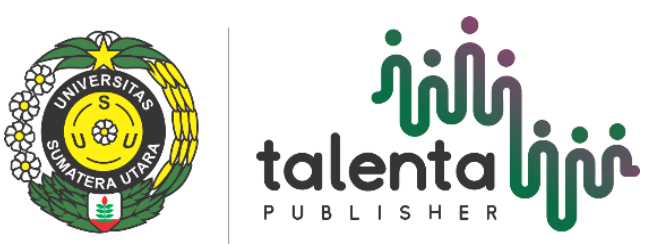


\title{
Kajian Performansi Kompor Surya dengan Erythrytol Sebagai Pcm untuk Memasak Langsung dan Tidak Langsung Safri Gunawan ${ }^{\mathrm{a} *}$, Farel Hasiholan Napitupulu ${ }^{\mathrm{b}}$, Himsar Ambarita ${ }^{\mathrm{b}}$
}

aFakultas Teknik, Universitas Sumatera Utara, Medan-20155, Indonesia

bPusat Riset Sustainable Energy, Universitas Sumatera Utara, Medan-20155, Indonesia

gunawan_safri@yahoo.com

\begin{abstract}
Abstrak
Menipisnya persediaan energi yang berasal dari fosil seperti minyak bumi, batu bara dan gas alam mengharuskan masyarakat beralih menggunakan energi alternatif. Dalam hal ini, Kementrian ESDM menghimbau untuk mencari dan mengembangkan energi alternatif sebagai pengganti energi konvensional. Salah satu energi alternatif yang harus dikembangkan adalah energi surya. Salah satu penggunaan energi surya dapat diaplikasikan dalam proses memasak. Tujuan penelitian ini adalah untuk mengetahui perubahantemperatur tiap titik pengukuran pada box kolektor surya dan vessel saat proses charging dan discharging, mengetahui perbandingan temperatur vessel yang menggunakan lug dan tidak menggunakan lug pada proses charging dan discharging, serta untuk mengetahui efesiensi termal box kolektor surya pada proses charging dan silinder isolator pada proses discharging dalam menjaga temperatur nasi. Pengujian pada proses charging dilakukan dengan menggunakan box kolektor berukuran $120 \times 120(\mathrm{~cm})$ dan pada proses discharging menggunakan silinder isolator berukuran $30 \times 45(\mathrm{~cm})$. Pada proses charging dilakukan pada pukul 10:00-16:00 WIB dan proses discharging pukul 16:00-09:00 WIB. Temperatur rata-rata proses charging untuk vessel menggunakan $\operatorname{lug}$ adalah $78,81{ }^{\circ} \mathrm{C}$ dan tidak menggunakan $\operatorname{lug}$ adalah $73,10{ }^{\circ} \mathrm{C}$. Hal ini terjadi karena pada vessel yang menggunakan lug dapat menyerap energi panas dari sisi bawah vessel. Sedangkan efesiensi yang diperoleh box kolektor surya tertinggi adalah pada proses charging $41,54 \%$ namun belum mampu meleburkan PCM yang memiliki temperatur lebur $120{ }^{\circ} \mathrm{C}$ karena temperatur maksimal yang mampu ditangkap box kolektor adalah $99,52{ }^{\circ} \mathrm{C}$.
\end{abstract}

Kata Kunci: Box Kolektor Surya; Silinder Isolator; Lug; PCM; Beras;

\section{Pendahuluan}

Direktur Aneka Energi Baru dan Terbarukan Kementerian Energi dan Sumber Daya Mineral (ESDM) Alihuddin Sitompul dalam acara Green Energy with Energy Financing di Universitas Trisakti mengatakan bahwa pencarian sumber daya alternatif menjadi suatu keharusan dalam mengantisipasi menipisnya persediaan energi yang berasal dari fosil seperti minyak bumi, batu bara, dan gas alam. Salah satu solusinya adalah pembuatan alat surya yang digunakan untuk memenuhi berbagai macam kebutuhan dengan memanfaatkan matahari sebagai sumber energi [1,2].

Penggunaan energi surya yang dikonversikan menjadi energi termal yang digunakan untuk memasak, mengeringkan hasil pertanian, dan memanaskan air telah berkembang pesat didaerah tropis dan subtropis di dunia. Salah satu energi surya yang sedang berkembang dan dikonversikan menjadi energi termal untuk keperluan memasak adalah kompor surya. Kompor surya adalah suatu alat penukar kalor yang menggunakan energi surya yang didisain untuk proses memasak [3]. Ditinjau dari mekanisme perpindahan panas yang digunakan untuk proses memasak, maka 
kompor surya diklasifikasikan menjadi dua tipe yaitu kompor surya dengan menggunakan media penyimpan panas dan kompor surya tanpa media penyimpan panas.

Berbagai desain kompor surya telah diteliti secara teoritis seperti penggunaan kombinasi cermin untuk mengoptimalkan kinerja kompor surya yang akan dihasilkan. Berawal dari kompor surya konvensional jenis kotak, Mirdha dan Dhariwal (2007) menyatakan bahwa kinerja kompor surya sangat dipengaruhi oleh desain dan pembuatannya seperti; (a) kompor surya konvensional jenis kotak dengan menggunakan cermin sebagai reflektor yang menghadap ke Selatan, (b) kompor surya konvensional jenis kotak dengan permukaan yang miring kearah Selatan dan cermin yang menghadap ke Selatan, (c) kompor surya konvensional jenis kotak dengan permukaan yang miring ke arah Selatan dan cermin yang menghadap ke Utara, (d) kompor surya konvensional jenis kotak dengan permukaan yang miring ke arah Selatan dan cermin yang menghadap ke Utara serta cermin vertikal yang menghadap ke Selatan, dan (e) kompor surya konvensional jenis kotak dengan menggunakan cermin sebagai refrektor yang dipasang vertikal dan miring menghadap ke Selatan dan cermin yang menghadap ke Utara [4].

Para peneliti telah meneliti beberapa aspek kompor surya dan mengklasifikasikan kompor surya secara luas kedalam kategori: (a) desain, pabrikasi, dan pengujian desain baru kompor surya, (b) metode peningkatanintensitas energi surya dengan menggunakan cermin, (c) jenis penyimpanan energi kompor surya dengan menggunakan PCM untuk digunakan didalam ruangan dan selamamataharitidakbersinar,dan (d) pengujian jenis kompor surya yang tergantungpadatempat memasak, teknik model, dan simulasi $[5,6]$.

Menambahkan pendapat mengenai peningkatan kinerja kompor surya, Reddy dan Rao juga mengemukakan bahwa kinerja kompor surya juga dapat meningkat dengan desain vessel yang merujuk pada material perpindahan panas yang baik, dan dengan memberikan pengganjal pada vessel yang digunakan sebagai media penyimpanan panas laten. Hal yang sama juga dijelaskan oleh Narasimha bahwa perpindahan panas pada permukaan bawah vessel akan lebih efektif bila diletakkan pengganjal di bawah permukaan karena dapat meningkatkan laju perpindahan panas pada permukaan bawah vessel $[7,8]$.

Dari uraian diatas dapat disimpulkan bahwa kinerja kompor surya sangat dipengaruhi oleh desain, metode, material penyimpanan panas laten (PCM) yang digunakan, danposisi vessel dalambox solar cooker. Hal inilah yang membuat peneliti ingin mendisain dan membuat kompor surya dengan menggabungkan beberapa kategori seperti desain, metode penambahan cermin sebagai reflektor, membandingkan vessel dengan dan tanpa pengganjal pada proses charging, dan menggunakan $3 \mathrm{~kg}$ erythritol sebagai PCM yang digunakan untuk memasak beras hingga menjadi nasi. Berdasarkan kajian yang telah diteliti diatas, maka peneliti memilih kompor surya konvensional jenis kotak dengan menggunakan cermin sebagai reflektor yang dipasang vertikal dan miring menghadap ke Selatan dan yang menghadap ke Utara untuk diteliti, karena desain tersebut merupakan desain dengan kinerja maksimal.

Secara khusus penelitian ini bertujuan untuk mengetahui perubahan temperatur tiap titik pengukuran pada box kolektor surya saat proses charging, mengetahui perbandingan temperaturvessel yang menggunakan pengganjal (lug) dan tidak menggunakan pengganjal (no lug) pada proses charging, mengetahui efesiensi termal box kolektor surya pada proses charging, mengetahui perubahan temperatur PCM dan nasi pada proses discharging, dan juga untuk mengetahui efesiensi termal silinder isolator pada proses discharging dalam menjaga temperatur nasi.

Manfaat dari penelitian ini dilihat dari sisi energi adalah untuk mengurangi penggunaan energi listrik dan bahan bakar fosil yang tidak dapat diperbaharui, dari sisi lingkungan adalah untuk mengurangi pemanasan global dengan menggunakan energi ramah lingkungan, dari sisi ekonomi sebagai peluang bisnis yang dapat digunakan dalam jangka panjang, dari sisi teknologi adalah untuk pengembangan teknologi energi thermal yang berpotensi mengurangi polusi udara di Indonesia, dan dari sisi akademis adalah untuk memberikan sumbangan data dan referensi yang diperlukan untuk penelitian selanjutnya.

\section{Metode dan Set-Up Eksperimen}

\subsection{Prinsip Kerja}

Prinsip kerja kolektor surya adalah dengan cara menyerap radiasi surya yang jatuh dipermukaan plat absorber yang berwarna hitam dan dikonversikan dalam bentuk panas, sehingga temperatur plat absorber menjadi naik. Temperatur 
pada plat absorber akan berpindah ke fluida kerja yang mengalir disekelilingnya secara konduksi, konveksi dan radiasi.Model kolektor surya yang akan dianalisa seperti ditunjukkan pada gambar 1, dimana kolektor surya ini terdiri dari beberapa komponen yang meliputi permukaan kaca penutup 1, gap udara 1, kaca penutup 2, g ap udara 2, vessel sebagai penyimpan panas laten, plat absorber, dan rangka yang terisolasi. Rangka dan isolasi menggunakan polywood, streofoam, dan glasswall.

Kehilangan energi panas pada kolektor surya terjadi dari bagian atas $\left(\mathrm{q}_{\mathrm{a}}\right)$, samping kanan $(\mathrm{qb})$, bawah $\left(\mathrm{q}_{\mathrm{c}}\right)$, dan samping kiri ( $(\mathrm{d})$. Indikator perubahan panas ditunjukkan pada perubahan temperatur lingkungan $\left(\mathrm{T}_{\mathrm{L}}\right)$, kaca penutup 1 (TK1), gap udara1 (TG1), kaca penutup 2 (ТK2), gap udara 2 (TG2), plat absorber (TPA), dan PCM (Тм) [9].

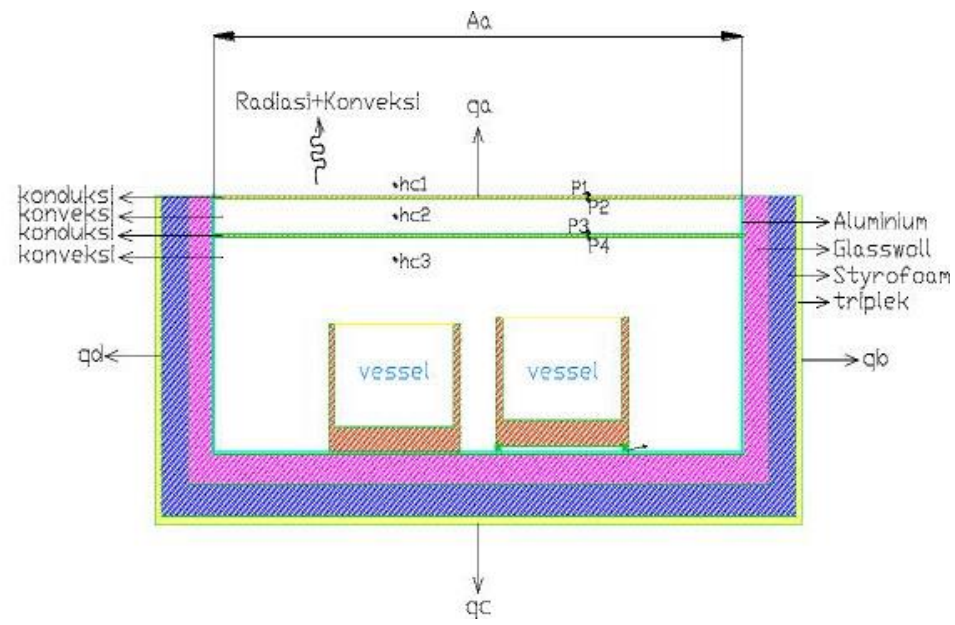

Gambar 1. Kolektor Surya

Nilai $\mathrm{q}_{\mathrm{a}}$ sebanding dengan perkalian koefisien kehilangan energi panas dari bagian atas $\left(\mathrm{U}_{\mathrm{a}}\right)$ dengan luas sisi kolektor bagian atas $\left(\mathrm{A}_{\mathrm{a}}\right)$ dan selisih temperatur plat absorber ${ }_{(\mathrm{TPA})}$ dan lingkungan $\left(\mathrm{T}_{\mathrm{L}}\right)$ dan secara matematis seperti persamaan (1)

$$
q_{a}=U_{a} \times A_{a} \times\left(T_{P A}-T_{L}\right)
$$

Sedangkan qb dihitung hampir sama dengan persamaan (1), tetapi nilaiUadiganti dengan koefisien kehilangan energy panas dari bagian bawah (Ub). Sedangkan luas sisi kolektor bagian bawah sama dengan atas $(\mathrm{Aa}=\mathrm{Ab})$. Sehingga kehilangan panas pada bagian bawah ditunjukkan pada persamaan (2).

$$
q_{b}=U_{c} x A_{c} x\left(T_{P A}-T_{L}\right)
$$

Pada $q_{b}$ dan $q_{d}$ dapat dihitung dengan $q_{s}$, dimana nilai koefisien $\mathrm{U}_{\mathrm{s}}$ dianggap sama dengan $\mathrm{U}_{\mathrm{c}}$ karena ketebalan isolasi dan kodisi lingkungan yang sama.Sedangkan luas sisi kolektor bagian samping $\left(\mathrm{A}_{\mathrm{s}}\right)$ merupakan luas total dari ke-4 sisi samping kolektor yaitu 2 sisi panjang dikali tinggi dengan 2 sisi lebar dikali tinggi. Sehingga $q_{s}$ dihitung dengan persamaan (3).

$$
q_{s}=U_{s} x A_{s} x\left(T_{P A}-T_{L}\right)
$$

Sehingga kehilangan energi panas total selama proses charging (qloses) seperti persamaan (4).

$$
q_{\text {loses }}=q_{a}+q_{b}+q_{s}
$$

Besarnya energi panas yang dikumpulkan oleh kolektor surya (qrad) dalam Watt dapat dihitung seperti pada persamaan (5). 


$$
q_{\text {rad }}=\alpha_{P A} \times \tau_{K 1} \times A_{K} \times I_{t}
$$

Dimana $\alpha_{\mathrm{PA}}$ adalah nilai absorsivitas dari plat absorber yang bergantung dari bahan material. Untuk bahan flat alumunium nilai absorsi vitas adalah 0,97. $\tau_{\mathrm{K}}$ merupakan transmisivitas kaca penutup yaitu 0,82 [9], $\mathrm{A}_{\mathrm{K}}$ adalah luas dari kolektor, dan $\mathrm{I}_{\mathrm{t}}$ adalah energi panas fusi yang diperoleh dari radiasi matahari.

Efisiensi termal kolektor surya adalah ukuran performasi dari peralatan termal tanpa dimensi. Efisiensi termal kolektor dapat dirumuskan dengan persamaan (6).

$$
\eta_{\text {th }}=\frac{Q_{\text {berguna }}}{Q_{\text {masuk }}}
$$

Berdasarkan definisi tersebut maka efisiensi termal pada kolektor surya plat datar dapat dihitung dengan persamaan (7).

$$
\eta_{K}=\frac{\sum q_{\text {rad }}-\sum q_{\text {loses }}}{\sum q_{\text {rad }}}
$$

Efisiensi termal vessel pada proses charging sangat bergantung pada tinggi panas yang mampu disimpan oleh PCM $\left(\Sigma \mathrm{q}_{\mathrm{PCM}}\right)$ perhari dan rendahnya energi panas yang hilang dari dinding kolektor $\left(\Sigma \mathrm{q}_{\mathrm{c}}+\Sigma \mathrm{q}_{\mathrm{s}}\right)$ serta berbanding terbalik dengan energi panas yang dikumpulkan oleh kolektor $\left(\Sigma \mathrm{q}_{\mathrm{rad}}\right)$. Secara matematis dapat dituliskan pada persamaan (8).

$$
\eta_{t h-c h}=\frac{\sum q_{P C M}-\left(\sum q_{c}+\sum q_{s}\right)}{\sum q_{\text {rad }}}
$$

Pengujianpada proses discharging terjadi pada saat material kembali membeku disertai dengan perpindahan panas dari PCM yang meleburkeberasdan air yang akan dimasak menjadi nasi. Perhitungan pada proses Discharging dapat dilakukan dengan persamaan (9) untuk pengujian energi panas yang diterima oleh beras, dan persamaan (10) untuk pengujian energi panas yang diterima oleh air, dan persamaan (11) untuk menghitung efisiensi thermal pada proses discharging seperti yang dipaparkan oleh Horward [10][11].

$$
\begin{gathered}
Q_{\text {air }}=\frac{m_{\text {air }} \cdot c_{\text {air }} \cdot \Delta T}{\Delta T} \\
Q_{\text {beras }}=\frac{m_{\text {beras }} \cdot c_{\text {beras }} \cdot \Delta T}{\Delta T} \\
\eta_{\text {si }}=\frac{Q_{\text {total air }}+Q_{\text {total beras }}}{Q_{P C M}}
\end{gathered}
$$

\subsection{Set-up Eksperimen}

Dalam eksperimen ini, dilakukan dua proses pengambilan data yaitu proses charging dan proses discharging. Proses charging seperti pada gambar 2.a. adalah proses dimana box kolektor surya diletakkan di luar ruangan pada saat matahari bersinar, vessel tembaga yang di dalamnya terdapat erythritol yang bersinggungan langsung dengan vessel aluminium berisi air dan beras kemudian dimasukkan ke dalam box kolektor surya. Dalam proses charging, terdapat dua vessel dalam dengan satu box kolektor surya dimana satu vessel tembaga diberi pengganjal dan satu vessel tembaga lainnya tanpa pengganjal. Waktu dalam proses charging adalah dari pukul 09:00 WIB-16:00 WIB. 
Setelah pukul 16:00 WIB, vessel tembaga dikeluarkan dari dalam box kolektor surya dan siap dimasukkan ke dalam silinder isolator.

Proses discharging seperti pada gambar 2.b. adalah proses kelanjutan dari proses charging, di mana proses discharging dilakukan untuk menjaga temperatur nasi dan PCM dalam silinder isolator tetap diatas temperatur kamar selama 17 jam masa pengujian dari pukul 16:00 WIB-09:00 WIB.

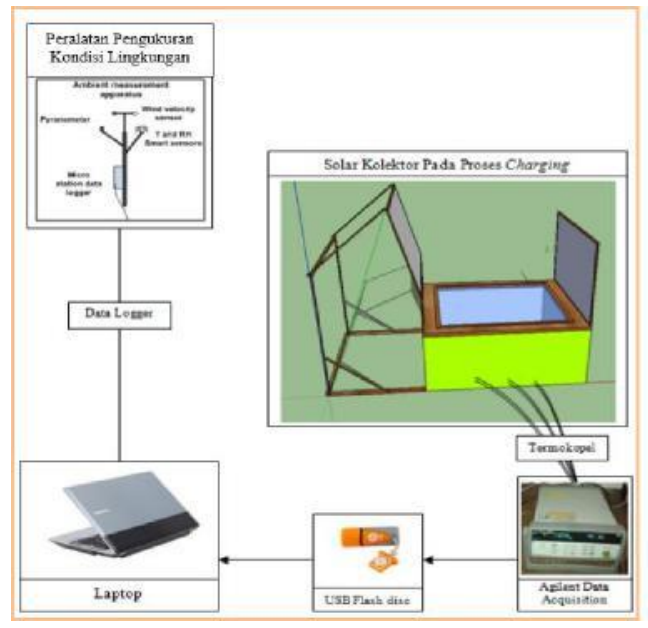

(a)

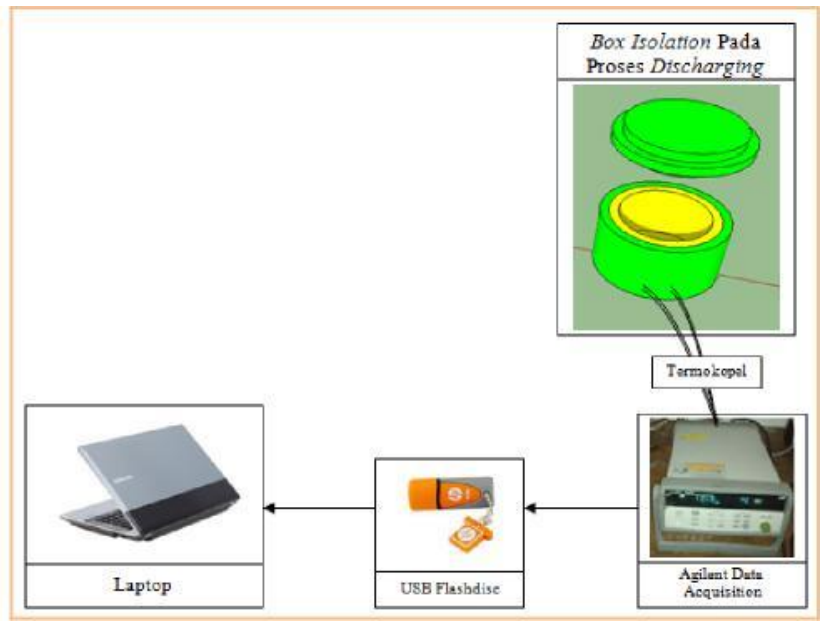

(b)

Gambar 2. Experimental Setup (a) Proses Charging dan (b) Proses Discharging

\subsection{Metode Memasak}

Berdasarkan latarbelakang, maka kotak kompor surya yang diteliti terdiri dari beberapa komponen utama seperti:

1. Pada proses charging

Pada proses ini, komponen yang digunakan adalah kolektor surya dan vessel. Kolektor surya yang digunakan memiliki komponen utama, yaitu kaca penutup, absorber, isolator, dan frame. Pada proses charging dilakukan penelitian dari pukul 10.00WIB-16.00WIB.

2. Pada proses discharging

Pada proses ini, komponen yang digunakan adalah silinder isolator dan vessel. Penelitian dilakukan dari pukul 16.00 WIB-09.00WIB

\section{Hasil dan Pembahasan}

Tahap pengujian ini dilakukan dengan 3 kali pengujian dan setiap pengujian dilakukan dengan 2 proses yaitu charging dan discharging.Secara umum, hasil pengujian pada proses charging didapat temperatur tertinggi secara berturut-turut terjadi pada plat absorber, kaca penutup 2, gap antara kaca penutup 1 dengan kaca penutup 2, dan terakhir pada kaca penutup 1 dengan pola kenaikkan meliputi intensitas radiasi matahari selama pengujian serta temperatur pada PCM, air dan beras naik secara polinomial hingga akhir pengujian. Sedangkan pada proses discharging, air dan beras telah menjadi nasi sehingga temperatur PCM dan nasi turun secara linear hingga akhir pengujian.

Pengujian pertama dilakukan pada tanggal 04 Januari 2016 dari pukul 10.00 WIB sampai dengan pukul 16.00 WIB untuk proses chargingseperti terlihat pada gambar 3.a. dan dilanjutkan dari pukul 16.00 WIB sampai dengan pukul 09.00 WIB untuk proses dischargingseperti pada gambar 3.b. Nilai rata-rata temperatur lingkungan, intensitas radiasi 
matahari, dan kecepatan angin adalah $33,02{ }^{\circ} \mathrm{C}, 478,77 \mathrm{~W} / \mathrm{m}^{2}$, dan $0,35 \mathrm{~m} / \mathrm{s}$. Potensi intensitas radiasi matahari total yang bisa dimanfaatkan adalah sebesar $28,726 \mathrm{MJ} / \mathrm{m}^{2}$.

Temperatur rata-rata hasil pengujian pada tanggal 04 Januari 2016 untuk proses charging yaitu: $\mathrm{Tk} 1=39,83^{\circ} \mathrm{C}, \mathrm{Tg}_{\mathrm{g}}$ $=72,18^{\circ} \mathrm{C}, \mathrm{T}_{\mathrm{k} 2}=76,74^{\circ} \mathrm{C}, \mathrm{T}_{\mathrm{r} 1}=77,61^{\circ} \mathrm{C}, \mathrm{T}_{\mathrm{p} 11}=78,81^{\circ} \mathrm{C}, \mathrm{T}_{\mathrm{p} 1}=73,10^{\circ} \mathrm{C}, \mathrm{T}_{\mathrm{p} 12}=66,76^{\circ} \mathrm{C}, \mathrm{T}_{\mathrm{p} 2}=65,61^{\circ} \mathrm{C}$ dan $\mathrm{T}_{\mathrm{pA}}=$ $81,72^{\circ} \mathrm{C}$, sedangkan untuk proses discharging yaitu: $\mathrm{T}_{\mathrm{p} 11}=42,15^{\circ} \mathrm{C}, \mathrm{T}_{\mathrm{p} 1}=37,17^{\circ} \mathrm{C}, \mathrm{T}_{\mathrm{p} 12}=41,04^{\circ} \mathrm{C}, \mathrm{T}_{\mathrm{p} 2}=39,39^{\circ} \mathrm{C}$.

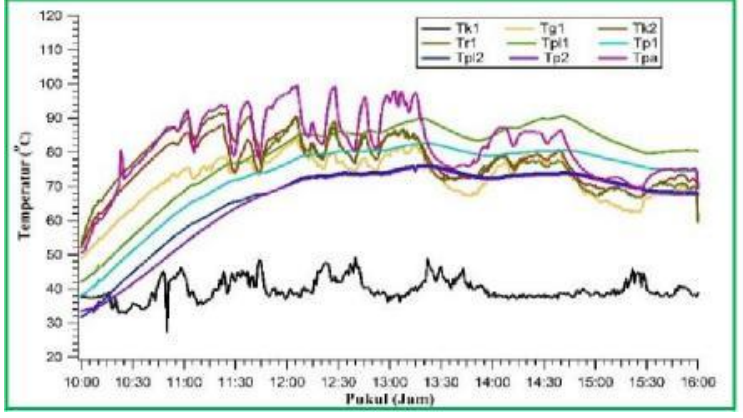

(a)

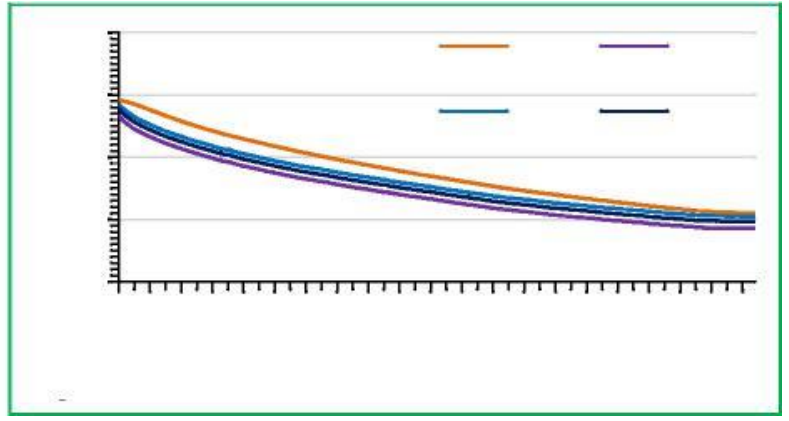

(b)

Gambar 3. Pengukuran Temperatur Kolektor dan PCM Pada Saat Proses Chargingdan Discharging Pada Pengujian Pertama

Hasil pengujian pada tanggal 06 Januari 2016 seperti gambar 4.a. dan gambar 4.b. memiliki temperatur rata-rata untuk proses charging yaitu: $\mathrm{T}_{\mathrm{k} 1}=43,63^{\circ} \mathrm{C}, \mathrm{T}_{\mathrm{g} 1}=57,90^{\circ} \mathrm{C}, \mathrm{T}_{\mathrm{k} 2}=60,17^{\circ} \mathrm{C}, \mathrm{T}_{\mathrm{r} 1}=62,60^{\circ} \mathrm{C}, \mathrm{T}_{\mathrm{p} 11}=64,68^{\circ} \mathrm{C}, \mathrm{T}_{\mathrm{p} 1}=69,04^{\circ} \mathrm{C}$, $\mathrm{T}_{\mathrm{p} 12}=66,66^{\circ} \mathrm{C}, \mathrm{T}_{\mathrm{p} 2}=59,72^{\circ} \mathrm{C}$ dan $\mathrm{T}_{\mathrm{pA}}=64,57^{\circ} \mathrm{C}$, sedangkan untuk proses discharging yaitu: $\mathrm{T}_{\mathrm{p} 11}=47,60^{\circ} \mathrm{C}, \mathrm{T}_{\mathrm{p} 1}=$ $42,68^{\circ} \mathrm{C}, \mathrm{T}_{\mathrm{p} 12}=48,04^{\circ} \mathrm{C}, \mathrm{T}_{\mathrm{p} 2}=47,10^{\circ} \mathrm{C}$.

Hasil pengujian pada tanggal 10 Januari 2016 seperti gambar 5.a. dan gambar 5.b. memiliki temperatur rata-rata untuk proses charging yaitu: $\mathrm{T}_{\mathrm{k} 1}=51,62^{\circ} \mathrm{C}, \mathrm{T}_{\mathrm{g} 1}=66,75^{\circ} \mathrm{C}, \mathrm{T}_{\mathrm{k} 2}=74,39^{\circ} \mathrm{C}, \mathrm{T}_{\mathrm{r} 1}=76,68^{\circ} \mathrm{C}, \mathrm{T}_{\mathrm{p} 11}=70,53^{\circ} \mathrm{C}, \mathrm{T}_{\mathrm{p} 1}=47,89^{\circ} \mathrm{C}$, $\mathrm{T}_{\mathrm{p} 12}=61,30^{\circ} \mathrm{C}, \mathrm{T}_{\mathrm{p} 2}=57,71^{\circ} \mathrm{C}$ dan $\mathrm{T}_{\mathrm{pA}}=78,98^{\circ} \mathrm{C}$, sedangkan untuk proses discharging yaitu: $\mathrm{T}_{\mathrm{p} 1}=57,51^{\circ} \mathrm{C}, \mathrm{T}_{\mathrm{p} 11}=$ $59,03^{\circ} \mathrm{C}, \mathrm{T}_{\mathrm{p} 12}=52,80^{\circ} \mathrm{C}, \mathrm{T}_{\mathrm{p} 2}=50,76^{\circ} \mathrm{C}$.

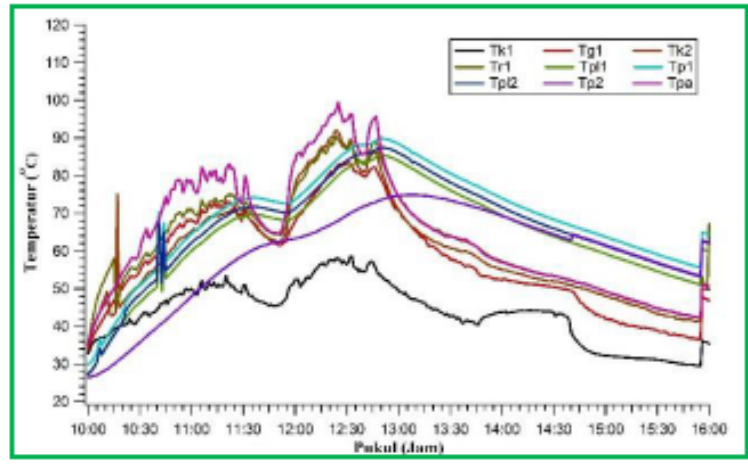

(a)

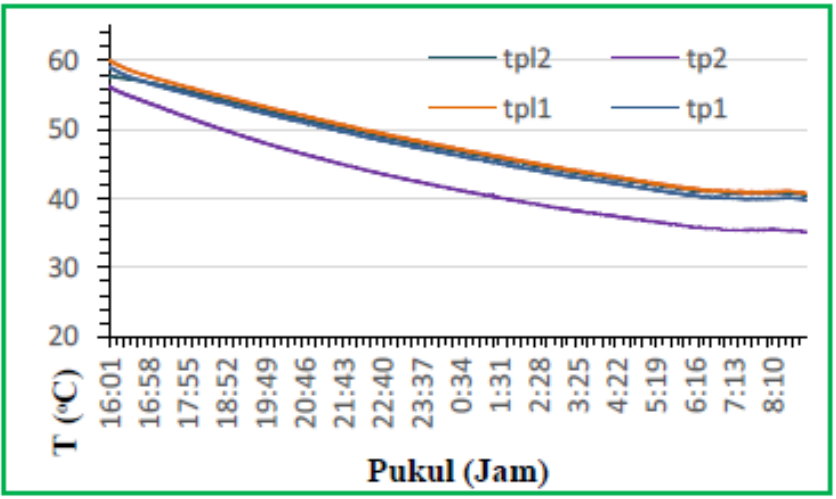

(b)

Gambar 4. Pengukuran Temperatur Kolektor dan PCM Pada Saat Proses Charging dan DischargingPada Pengujian Kedua 


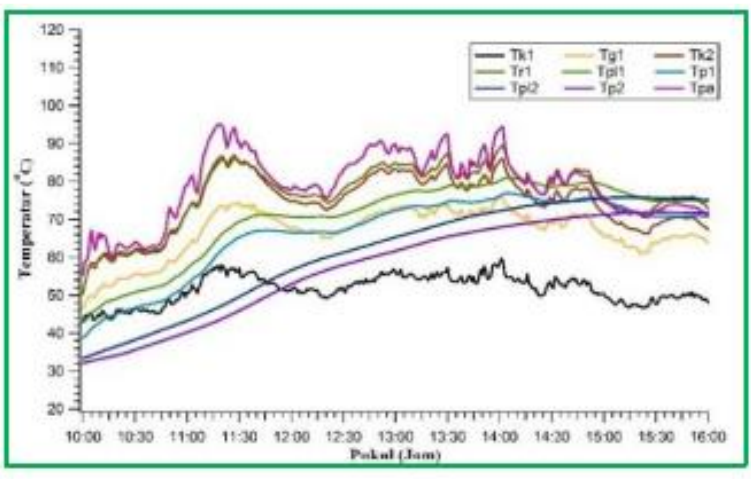

(a)

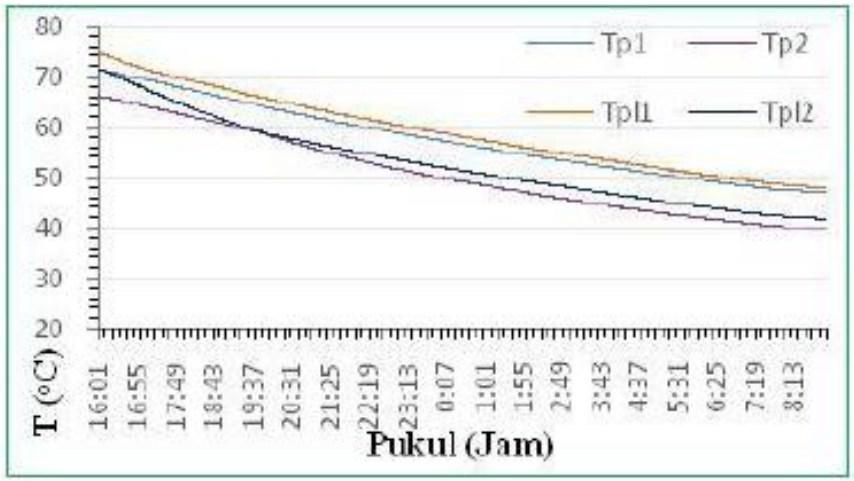

(b)

Gambar 5. Pengukuran Temperatur Kolektor dan PCM Pada Saat Proses Charging dan Discharging Pada Pengujian Ketiga

Efesiensi termal untuk proses charging seperti pada Tabel 1.

Tabel 1. Efesiensi termal proses charging

\begin{tabular}{lllllll}
\hline Tanggal Pengujian & $\sum \mathrm{q}_{\mathrm{rad}}$ & $\sum \mathrm{q}_{\mathrm{v}}$ & $\sum \mathrm{q}_{\mathrm{a}}$ & $\sum \mathrm{q}_{\mathrm{b}}$ & $\sum \mathrm{q}_{\mathrm{s}}$ & Eth-c \\
\hline 04 Januari 2016 & 8,24851 & 2,70106 & 0,01102 & 0,31733 & 0,76159 & 19,5322 \\
06 Januari 2016 & 5,22532 & 1,08084 & 0,00514 & 0,20153 & 0,48368 & 7,47312 \\
10 Januari 2016 & 9,2076 & 4,80588 & 0,00564 & 0,28669 & 0,68806 & 41,5471 \\
\hline
\end{tabular}

Efesiensi termal untuk proses discharging seperti pada Tabel 2.

Tabel 2. Efesiensi proses discharging

\begin{tabular}{llllll}
\hline $\begin{array}{l}\text { Tanggal } \\
\text { Pengujian }\end{array}$ & Kondisi Vessel & air $(\mathrm{KW})$ & beras (KW) & pcm (KW) & Esi (\%) \\
\hline 04 Januari & With Lug & 0,0007328 & 0,0003479 & 0,0030579 & 35,34 \\
2016 & Without Lug & 0,0007314 & 0,0003477 & 0,0029951 & 36,03 \\
04 Januari & With Lug & 0,0005204 & 0,0002488 & 0,0014940 & 51,49 \\
2016 & Without Lug & 0,0006347 & 0,0003043 & 0,0014818 & 63,37 \\
04 Januari & With Lug & 0,0011984 & 0,0005694 & 0,0022844 & 77,38 \\
2016 & Without Lug & 0,0010798 & 0,0005146 & 0,0020362 & 78,30 \\
\hline
\end{tabular}

\section{Kesimpulan}

Dari hasil pengujian yang dilakukan terhadap vessel tembaga dan vessel aluminium yang terintegrasi dalam box kolektor surya pada proses charging dan silinder isolator pada proses discharging, maka diperoleh kesimpulan, yaitu: Kenaikan temperatur pada plat kolektor akan mempengaruhi kenaikan temperatur vessel yang terintegrasi dalam box 
kolektor surya. Semakin tinggi temperatur plat kolektor maka semakin banyak panas yang disimpan oleh vessel PCM. Temperatur rata-rata vessel dengan menggunakan pengganjal lebih tinggi dibandingkan temperatur vessel yang tidak menggunakan pengganjal yaitu $78,81^{\circ} \mathrm{C}$ dan $73,10^{\circ} \mathrm{C}$. Hal ini terjadi karena vessel yang menggunakan pengganjal dapat menyerap energi panas pada sisi bawah vessel tersebut dan vessel yang tidak menggunakan pengganjal tidak dapat menyerap energi panas dari sisi bawah vessel.Efisiensi termal pada proses charging tertinggi diperoleh pada tanggal 10 Januari 2016 yaitu 41,54\%. Hal ini disebabkan karena pada tanggal tersebut intensitas radiasi matahari tinggi.Efisiensi termal tertinggi pada proses discharging selama 17 jam pengujian diperoleh pada tanggal 10 Januari 2016 yaitu 77,38\% untuk vessel dengan pengganjal dan 78,30\% untuk vessel tanpa pengganjal. Efesiensi ini dipengaruhi oleh massa nasi yang semakin tinggi, dimana semakin tinggi massa nasi, maka akan semakin lama nasi tersebut menyimpan energi panas.

\section{Referensi}

[1] Aremu A.K, Igbeka J.C, Energetic and Exergetic Evaluation of Box-Type Solar Cookers Using Different Insulation Materials, 2015.

[2] Francis C, Jose V., A Review on Performance Improvements in Box Type Solar Cookers, 2015.

[3] Google, (online), Energi Fosil Menipis, Solar Cell Jadi Solusi, http://www.republika.co.id/berita/ekonomi/bisnis/13/05/27/mnga8h-energi-fosil-menipis-solar-cell-jadi-solusi, tanggal akses 17 Juli 2013 jam 13:55 WIB.

[4] Howard, Pengujian Solar Cooker Tipe Kotak Sederhana Sebagai Pemasak, Skripsi, USU; 2012.

[5] Jufrizal, Studi Eksperimental Performansi Thermal Energy Storage yang Terintegrasi Dalam Kolektor Surya Plat Datar, USU; 2013.

[6] Mirdha U.S, Dhariwal S.R, —Design Optimization of Solar Cooker", India; 2007.

[7] Napitupulu F.H, Tabel Grafik dan Diagram untuk Perpindahan Panas, Bahan Ajar; 2010.

[8] Narasimha Rao A.V, S.S —Solar Cookers-Part 1: Cooking Vessel On Lugs", India; 2003.

[9] Rikoto I.I, Garba I., Comparative Analysis on Solar Cooking Using Box Type Solar Cooker with Finned Cooking Pot, Kano, 2013.

[10] Vala Raji Reddy, Narasimha Rao A.V. - Prediction and Experimental Verification of Performance of Box Type Solar Cooker-Part 1. "Cooking Vessel With Central Cylinderical Cavity", India; 2007.

[11] Vala Raji Reddy, Narasimha Rao A.V. —Prediction and Experimental Verification of Performance of Box Type Solar Cooker. Part 2: Cooking Vessel With Depressed Lid", India; 2007. 